\title{
Effect of Plyometric Jumping Jack and Tuck Jump Against Strength and Leg Muscle Power in Martial Arts Athletes at Kostrad Malang
}

\author{
Abdul Hafidz ${ }^{1, *}$ Shidqi Hamdi Pratama Putera ${ }^{2}$, Afif Rusdiawan ${ }^{3}$
}

\begin{abstract}
${ }^{1,2}$ Department of Sport Coaching Education, Universitas Negeri Surabaya, Surabaya, Indonesia
${ }^{3}$ Department of Health Education and Recreation, Universitas Negeri Surabaya, Surabaya, Indonesia

*Corresponding author.Email: abdulhafidz@unesa.ac.id
\end{abstract}

\begin{abstract}
The purpose of this study was to determine the effect of jumping jack and tuck jump exercises on leg muscle strength and power. The subjects of this study were the Pencak silat athletes of the Branch Kostrad Company-C, totaling 30 people who were divided into three groups with ten people in each group and carried out for six weeks. The type of research used in this research is quantitative with an experimental method. The research design used a Non-Randomize Control Group Pretest-Posttest Design. Data collection on leg muscle strength was carried out by testing the Leg Dynamometer and leg muscle power using the Jump MD tool at the pretest and posttest. The results of the study were measured using paired t-test and LSD tests. The paired t-test obtained sig <0.05 on the variable leg muscle strength and leg muscle power. The results of the LSD test show that jumping jack exercise has more effect on the ability of leg muscle strength and power. In conclusion, jumping jacks and tuck jump exercises can improve leg muscle strength and power, where jumping jacks practice has more effect on the knowledge and stability of the leg muscles.
\end{abstract}

Keywords: Plyometric exercises, Exercise jumping jacks, Tuck jumps

\section{INTRODUCTION}

Chu (2013) Plyometric training is a form of exercise that allows forces to achieve maximum strength in the shortest possible time; plyometric training combines strength and speed to produce strength and power, involving more muscle fibers to have the complete physical ability. Leg muscle strength and power are significant in Pencak silat to support the kick technique[1][2]. Plyometric exercise methods dominate the formation of stability and strength of the leg muscles [3]. Anatomically hurdle hops and tuck exercises, the muscles involved are thigh flexion, which consists of the sartorius, gracilis, and ill acts muscles, affecting the tensor fasciae latae, lateral, medial, intermediate, and rectus femoris muscles. For athletes who have a fast and robust kick will have a significant impact for victory because when performing a kick attack technique that is applied will not be quickly slammed by the opponent, as well as the accuracy of the kick technique that is both difficult to be fended off or attacked by the opponent, then the effect caused in the form of a loud sound generated from the opponent's body protector and can change the opponent's position to be unbalanced. Or the opponent falls. Referring to Chou, L. \& Link, N. (2011) titled The Anatomy of Martial ARTS. This is proven during various events that followed the resulting predation less maximal, lack of strength and strength of the limb muscles in athletes Pencak silat Twig Kostrad Kompi-C Malang can cause the resulting kick is weak and can cause a rush that is easily captured by the opponent so that when getting an excellent opportunity to shoot a lift into the body protector of the opponent's body becomes unable to do. And research from Delavier, F. \& Gundill, M. (2011) when Pencak silat athletes steal points from opponents during matches using kicks with the help of strength and power of the limb muscles [1]. Based on direct observations done by researchers with the coach of Twig Kostrad Kompi-C Pencak silat, it turns out with relatively the same technique when sparing, and the resulting kick match is still not good.

The results of observations and data obtained by researchers during interviews with coaches, it can be known that the training methods provided by coaches to athletes still use old training methods and only rely on the experience of coaches who have been athletes without being supported by the scientific literature in the formation of physical conditions. Comparison of novelty results of excellence and previous theoretical studies with current research, similarities, differences, and techniques, namely analysis. Faidlulah \& Kuswandari (2009) The effect of Plyometric Depth Jump and Knee Tuck Jump exercises on the results of beginner football athletes' gastric kicks in Al-Firdaus Surakarta Junior High School, this study aims to examine and find out if there is a significant difference between the influence of depth jump training and knee tuck jump on the results of gastric kicks. This research results conclude that depth jump exercises influence the outcomes of gastric spices [4]. As for the differences, advantages, and similarities of previous research, research II, with the current study, uses plyometric tuck jump, while the difference in training is also influenced by speed. While the 
advantage in research now is to have a plyometric exercise method that focuses more on the strength of the muscles involved is theoretically able to increase the strength and power of the limb muscles. While the research Ayuningtyas, Hartono \& Rahayu (2015) The effect of Side Hop and Jump To Box exercises on the power of the limb muscles and leg muscle strength in students of the ball extension of SMK Mataram Semarang. This study aims to examine and find out if there is a significant difference between the influence of Side Hop and Jump To Box exercises on leg muscle power and leg muscle strength. The result is that the jump to box exercises influences leg muscle power and leg muscle strength in students of the Mataram Semarang Semarang high school in 2015 [5]. As for the differences, advantages, and similarities of previous research, research I, with analysis now, is equally using plyometric exercises to increase the strength of the limb muscles. While the different research places and other samples. While the advantage in research now is to have a plyometric exercise method that focuses more on the strength of the muscles involved, it is theoretically able to increase the strength and power of the limb muscles. Therefore, researchers want to provide plyometric jumping jack exercises and tuck jump training practices to Pencak silat Twig Kostrad Kompi-C athletes. In this study, the sport of Pencak silat is suitable for use in the application of plyometric hurdle hop and tuck jump because in the game Pencak silat kick technique requires strength and power when performing this movement.

\section{METHODS}

In this type of research, researchers use quantitative research methods. The approach used in this study is a pseudo experiment (quasi-experiment) with a research design using the design "Non-Randomized PreTest PostTest Control Group Design."

In determining the number of samples to be used in this study, the sampling technique used is Simple Random Sampling, which is the sampling of members of the population is done simply. That for experimental research is divided into various groups, then the number of sample members each between 10 to 20. As for the formation of groups in this study will separate three groups, namely experimental group 1, experiment 2, and control group, then the pairing used is ordinal pairing, based on ordinal pairing techniques so that the samples in this study will be grouped as follows, group $A=10$ people were given the treatment of jumping jacks training, group $\mathrm{B}=$ ten people were given tuck jump training treatment, group $\mathrm{C}=$ ten people as a control group, so the total sample number of 30 people tried. To generalize the ability of the subject, it takes efforts to standardize the score by using in statistical terminology that is a standard score, namely Z-score, a standard score $(Z)$ is a number that shows how far a score deviates from the mean $(\mathrm{M})$ in the standard deviation unit (SD). To avoid negative or decimal numbers generated through $\mathrm{Z}$-score calculations. So the statistical method provides a way out, namely by transforming it into T-score. The time and place of this study were carried out six weeks, in the sports center
Kartini Malang. Treatment as a limit to the ability of each individual to do exercise before being presented to a power intensity of $60-80 \%$. Adaptation can already be obtained results approximately four to five days after training. Still, after the exercise lasts several weeks, Anaerobic interval training will stimulate physiological adaptation significantly in 2 to 15 weeks in untrained individuals [6]. So, according to the theory, the increase in intensity for two weeks has been able to adapt physiologically to the weight of exercise provided. The study used this type of test to measure the strength of leg muscles using a leg dynamometer. As for measuring power using a jump MD tool.

To give meaning to the data in this study, the type of data collected in this study is a test of strength and strength of the limb muscles and the height of the achievements of both types of exercise of each group. After that, the test results will be recorded and calculated based on the group and type of training applied, data analysis using descriptive statistical techniques, normality tests, homogeneity tests, hypothesis tests, and research with the help of the SPSS 22.0 computer program.

\section{RESULTS AND DISCUSSION}

Here are the study results based on the limb strength test using the leg dynamometer test tool and the power test using the jump MD test given to experiment group I, experiment group II, and the control group. The Result and Discussion will be outlined about the description of the data, the terms of the hypothesis test, and the hypothesis test results.

\subsection{Results}

The description of the data that will be presented in the form of data on the results of the strength test of the limb muscles and the strength of the limb muscles before (pretest) and after (posttest) is given treatment in each group which includes: group I jumping jacks, group II tuck jump, and group III control

In jumping jacks data obtained pretest and posttest data for both limb muscle strength and limb muscle power, the data includes meaning average, maximum value, minimum value, and standard deviation.

Table 1. Descriptive analysis of pretest and posttest result of Jumping Jacks

\begin{tabular}{|c|c|r|r|r|r|}
\hline & $\mathrm{N}$ & \multicolumn{1}{c|}{ Mean } & \multicolumn{1}{c|}{$\begin{array}{c}\text { Std. } \\
\text { Deviation }\end{array}$} & Minimum & Maximum \\
\hline $\begin{array}{c}\text { Pretest } \\
\text { Strength }\end{array}$ & 10 & 130.60 & 26.592 & 90 & 165 \\
\hline $\begin{array}{c}\text { Postest } \\
\text { strength }\end{array}$ & 10 & 162.50 & 22.486 & 125 & 190 \\
\hline $\begin{array}{c}\text { Pretest } \\
\text { Power }\end{array}$ & 10 & 436.6540 & 152.12220 & 211.02 & 786.73 \\
\hline $\begin{array}{c}\text { Postest } \\
\text { Power }\end{array}$ & 10 & 592.0210 & 160.05977 & 448.45 & 995.15 \\
\hline & & & & & \\
\hline
\end{tabular}

Based on mean calculations, the jumping jack group training results experienced an increase in the average results of strength and strength of the limb muscles. This can be seen from 
the pretest, and posttest data of leg muscle strength which was originally $130.60 \mathrm{Kg}$ increased to $162.50 \mathrm{Kg}$, and pretest and posttest power of leg muscles which were originally 436.65 Joule, increased to 592.02 Joule. While different tests with paired-T tests showed that the level of significance of each variable obtained sig $<0.05$ thus, there is a significant influence, or there is a difference between pretest and posttest data from each variable bound to both the strength of the leg muscle and the power of the leg muscles.

In tuck jump exercises obtained pretest and posttest data were obtained for both limb muscle strength and limb muscle power. The data includes mean averages, maximum values, minimum values, and standards.

Table 2. Descriptive analysis of pretest and posttest result of tuck jump

\begin{tabular}{|c|c|r|r|r|r|}
\hline & $\mathrm{N}$ & \multicolumn{1}{|c|}{ Mean } & \multicolumn{1}{c|}{$\begin{array}{c}\text { Std. } \\
\text { Deviation }\end{array}$} & Minimum & Maximum \\
\hline $\begin{array}{c}\text { Pretest } \\
\text { Strength }\end{array}$ & 10 & 115.60 & 34.245 & 60 & 166 \\
\hline $\begin{array}{c}\text { Postest } \\
\text { Strength }\end{array}$ & 10 & 130.60 & 25.526 & 98 & 175 \\
\hline $\begin{array}{c}\text { Pretest } \\
\text { Power }\end{array}$ & 10 & 431.1080 & 90.32002 & 300.84 & 569.86 \\
\hline $\begin{array}{c}\text { Postest } \\
\text { Power }\end{array}$ & 10 & 530.2380 & 87.94283 & 405.79 & 688.48 \\
\hline & & & & & \\
\hline
\end{tabular}

Based on the results of research by providing tuck jump exercises with the average results of leg muscle strength and limb muscle power. This can be seen from the pretest, and posttest data of the strength of the leg muscles, which were originally $115.60 \mathrm{Kg}$ increased to $130.60 \mathrm{Kg}$, and the pretest and posttest Power of the leg muscles that were initially 431.08 Joule increased to 530.23 Joule. From the results of different tests with paired-T test obtained sig $<0.05$ both the average difference between pretest data and posttest strength of leg muscles and limb muscle power so that it is concluded that there is a significant influence of tuck jump exercise method on the strength and strength of the leg muscles.

The control group obtained pretest and posttest data on both limb muscle strength and limb muscle power. The data includes meaning (average), maksimal value, minimum value, and standard deviation.

Table 3. Descriptive analysis of pretest dan posttest control group

\begin{tabular}{|c|c|r|r|r|r|}
\hline & $\mathrm{N}$ & \multicolumn{1}{|c|}{ Mean } & \multicolumn{1}{c|}{$\begin{array}{c}\text { Std. } \\
\text { Deviation }\end{array}$} & Minimum & Maximum \\
\hline $\begin{array}{c}\text { Pretest } \\
\text { Strength }\end{array}$ & 10 & 106.80 & 13.637 & 89 & 128 \\
\hline $\begin{array}{c}\text { Postest } \\
\text { strength }\end{array}$ & 10 & 117.00 & 13.606 & 95 & 135 \\
\hline $\begin{array}{c}\text { Pretest } \\
\text { Power }\end{array}$ & 10 & 365.2890 & 75.49799 & 236.08 & 482.40 \\
\hline $\begin{array}{c}\text { Postest } \\
\text { Power }\end{array}$ & 10 & 438.4640 & 64.25645 & 358.97 & 567.69 \\
\hline & & & & & \\
\hline
\end{tabular}

The control group results experienced an increase in the average results of strength and strength of the limb muscles. This can be seen from the pretest, and postest strength data of the leg muscles, which were initially $106.80 \mathrm{Kg}$ increased to $117.00 \mathrm{Kg}$. The pretest and posttest power of the leg muscles that were initially 365.28 Joule increased to 438.46 Joule from the analysis of paired-T Tests found the pretest and posttest values of leg muscle strength and limb muscle strength had sig values $<0.05$ on variable strength of limb muscles and limb muscle power. This means that there is a significant difference between the pretest and posttest strength of the limb muscles and the strength of the leg muscles.

In performing the hypothesis test, different variables are bound to a paired sample using a t-test analysis which in SPSS is called a paired t-test. While the hypothesis tests other variables bound between groups using analysis of variance.

To find out more about the results of the t-test conducted in each group, it can be seen in the table below:

Table 4. Paired Sample t-test of strength

\begin{tabular}{|c|c|c|c|c|}
\hline & & Mean & $\mathrm{t}$ & Sig. (2tailed \\
\hline $\begin{array}{c}\mathrm{K} \\
1\end{array}$ & $\begin{array}{c}\text { Postest Strength } \\
\text { Pretest Strenght }\end{array}$ & 31.900 & 10.550 & .000 \\
\hline $\begin{array}{c}\mathrm{K} \\
2\end{array}$ & $\begin{array}{c}\text { Postest Strenght } \\
\text { Pretest Strenght }\end{array}$ & 15.000 & 3.631 & .005 \\
\hline $\begin{array}{c}\mathrm{K} \\
3\end{array}$ & $\begin{array}{c}\text { Postest Strenght } \\
\text { Pretest Strenght }\end{array}$ & 10.200 & 5.220 & .001 \\
\hline
\end{tabular}

Table 5. Paired Sample t-test of power

\begin{tabular}{|c|c|c|c|c|}
\hline & & Mean & $\mathrm{t}$ & Sig. (2tailed \\
\hline $\mathrm{K}$ & $\begin{array}{l}\text { Postest Power } \\
1\end{array}$ & 155.36700 & 10.033 & .000 \\
\hline $\begin{array}{c}\text { K } \\
2\end{array}$ & $\begin{array}{c}\text { Postest Power Power } \\
\text { Pretest Power }\end{array}$ & 99.130000 & 7.509 & .000 \\
\hline $\begin{array}{c}\mathrm{K} \\
3\end{array}$ & $\begin{array}{l}\text { Postest Power } \\
\text { Pretest Power }\end{array}$ & 73.17500 & 5.175 & .001 \\
\hline
\end{tabular}

Based on the two tables above, it shows that the significant level of each variable obtained sig $<0.05$; thus, there is a considerable influence or difference between the pretest and posttest of each bound variable (strength of the limb muscle and limb muscle power) in both the experimental group I, experimental group II, and experimental group III. So it can be concluded that there was a difference after being given a program of jumping jacks, tuck jump exercises, and the control group.

In conducting different tests, the data tested was the mean difference of the three groups tested together. Other tests in this study were conducted with the Anova (F) test, and the result was to find out whether or not there was a difference in the mean difference in each group simultaneously. The test results can be seen in the table below. 
Table 6. Result of Anova test

\begin{tabular}{|c|c|c|}
\hline Variable & F & Sig. \\
\hline Strenght & 12.191 & 0.000 \\
\hline Power & 4.778 & 0.017 \\
\hline
\end{tabular}

Based on the results in the table above, it shows that the significant value of the Anova Test on strength and strength of the limb muscles is sig $<0.05$. So it can be concluded that there are substantial differences in the power of the limb muscles and the strength of the limb muscles in three different groups. Therefore, with the difference in influence between groups, data analysis can be continued by developing post hoc multiple corporations tests using Least Significant Difference (LSD) analysis in the SPSS series 22.0 program, which aims to find out which free variables have a significant influence on the increase inbound variables.

Table 7. Result of LSD test

\begin{tabular}{|c|c|c|c|c|c|}
\hline \multirow{2}{*}{$\begin{array}{l}\text { VARI } \\
\text { ABEL }\end{array}$} & \multirow[t]{2}{*}{ (I) } & \multirow[t]{2}{*}{$(\mathrm{J})$} & \multirow[t]{2}{*}{ Sig } & \multicolumn{2}{|c|}{$\begin{array}{l}\text { 95\% Confidence } \\
\text { Interval }\end{array}$} \\
\hline & & & & $\begin{array}{l}\text { Lower } \\
\text { bound }\end{array}$ & $\begin{array}{l}\text { Upper } \\
\text { bound }\end{array}$ \\
\hline \multirow{5}{*}{$\begin{array}{c}\text { Streng } \\
\quad h t\end{array}$} & \multirow{2}{*}{$\begin{array}{c}\text { Jumping } \\
\text { jacks }\end{array}$} & $\begin{array}{l}\text { tuck } \\
\text { jump }\end{array}$ & .001 & 7.72 & 26.08 \\
\hline & & Kontrol & .000 & 12.52 & 30.88 \\
\hline & \multirow[t]{2}{*}{ tuck jump } & $\begin{array}{l}\text { Jumpin } \\
\text { g jacks }\end{array}$ & .001 & -26.08 & -7.72 \\
\hline & & Kontrol & .293 & -4.38 & 13.98 \\
\hline & \multirow[t]{2}{*}{ Kontrol } & $\begin{array}{l}\text { Jumpin } \\
\text { g jacks }\end{array}$ & .000 & -30.88 & -12.52 \\
\hline \multirow{7}{*}{ Power } & & $\begin{array}{l}\text { tuck } \\
\text { jump }\end{array}$ & .293 & -13.98 & 4.38 \\
\hline & \multirow{2}{*}{$\begin{array}{c}\text { Jumping } \\
\text { jacks }\end{array}$} & $\begin{array}{l}\text { tuck } \\
\text { jump }\end{array}$ & .010 & 14.7225 & 97.7515 \\
\hline & & Kontrol & .000 & 40.6775 & 123.7065 \\
\hline & \multirow[t]{2}{*}{ tuck jump } & $\begin{array}{l}\text { Jumpin } \\
\text { g jacks }\end{array}$ & .010 & -97.7515 & -14.7225 \\
\hline & & Kontrol & .210 & -15.5595 & 67.4695 \\
\hline & \multirow[t]{2}{*}{ Kontrol } & $\begin{array}{l}\text { Jumpin } \\
\text { g jacks }\end{array}$ & .000 & $123 . \overline{7065}$ & -40.6775 \\
\hline & & $\begin{array}{l}\text { tuck } \\
\text { jump }\end{array}$ & .210 & -67.4695 & 15.5595 \\
\hline
\end{tabular}

Based on table 7 above shows that there is a significant difference in mean difference between the jumping jack group and the tuck jump group, and the control group in both the strength variable and the power of the limb muscles. The jumping jack group showed differences in variable strength, with the tuck jump group showing lower bound 7.72 and upper bound 26.08. In contrast, the difference with the control group showed that lower determined 12.52 and upper committed 30.88 The tuck jump group showed differences in variable strength with the jumping jack group showing lower bound 26.08 and upper bound -7.72. In contrast, the difference with the control group showed lower bound -4.38 and upper bound 13.98. The control group showed differences in variable strength, with the jumping jack group showing lower bound 30.88 and upper bound -12.52 , while differences with control groups showed lower bound -13.98 and upper bound 4.38. The jumping jack group showed differences in variable power, with the tuck jump group showing that the lower bound was 14.7225 and the upper bound 97.7515, while the control group showed the lower bound 40.6775 and the upper bound 123.7065 . The tuck jump group showed differences in variable power, with the jumping jack group showed lower bound -97.7515 and upper bound -14.7225 , while the difference with the control group showed lower bound -15.5595 and upper bound 67.4695. The control group showed differences in variable power, with the jumping jack group showing lower bound -123.7065 and upper bound -40.6775 . In contrast, the difference with the control group showed that lower bound -67.4695 and upper bound 15.5595. Based on these results, it can be concluded that jumping jack exercises have more effect on the strength and strength of the limb muscles compared to tuck jump exercises and control groups

\subsection{Discussion}

Knowing the most effective exercise methods to increase the strength and strength of the limb muscles becomes essential. The analysis results with the ANOVA test on mean different jumping jacks, tuck jump, and control groups obtained sig $<0.05$ means that there is a significant difference in the strength of the limb muscles and the strength of the limb muscles in three different groups. Lsd's Post Hoc test results showed a mean difference between the jumping jacks, tuck jump, and control groups, both on strength variables and limb muscle power. Based on these results, it can be concluded that jumping jacks exercises have more effect on the strength and strength of the limb muscles compared to tuck jump exercises and control groups. Based on a comparison of plyometric jumping jacks and tuck jump exercises.

There is a difference in the influence of the strength of the limb muscles and the strength of the leg muscles where the jumping jacks exercise is better than the tuck jump training exercise. This happens because, in jumping jacks, the contraction of the muscles in the legs increases compared to muscle contractions in tuck jump exercises. When observing the study of theory based on "power is the result of times speed and strength" [7]. Based on this theory, it is known very clearly that the amount of strength is directly proportional to the amount of power, which means that if the force increases, then the power also increases.

The jumping jack is an essential explosive move in many sports. Jumping jacks are performed by jumping with the legs spread wide and the hands clapping above the head accompanied by the feet returning to the docked position [8][9]. 
Jumping jacks can improve coordination, strengthen leg muscles and improve cardiovascular ability [10]. Tuck Jump is a plyometric exercise that aims to increase the explosive power of the lower leg muscles. The tuck jump is done in a standing body position, the feet are shoulder-width apart, and the palms face down at chest level, then jump up quickly and move the knees up towards the chest and try to touch the palms and then land on both feet. Knee tuck jump is a plyometric exercise that aims to increase the explosive power of the lower leg muscles [11]. The explosive power of leg muscles is the ability to exert their maximum strength quickly to achieve the desired goal in sports performance [12].

Thus, when doing movements, the work of the leg muscles will also be heavier so that the workload of the leg muscles in jumping jacks exercises is heavier than tuck jump exercises. The resulting impact is stress because the leg muscles are more increased in jumping jacks training, so jumping jacks exercise is heavier in putting weight on the leg muscles. Therefore, the increase in strength of the leg muscles and the power of the leg muscles between jumping jacks and tuck jump exercises is different where the leg muscles in the jumping jacks group are more improved. Comparison of novelty results of excellence and previous theoretical studies with current research, similarities, differences, and techniques, namely analysis. Krsitian Kungku (2014) The influence of hurdle hops and multiple boxes to box squat jumps on the power of the leg muscles vertically and the distance of the jump without a prefix, aims to examine and find out if there is a significant difference between the effect of hurdle hops and multiple boxes to box squat jump on the power of the leg muscles vertically and the distance of the jump without a prefix. This study shows the effect of hurdle hops and multiple box-to-box squat jumps on the power of the leg muscles vertically and the distance of the jump without a prefix. Similarities and differences of research, previous research with the current study uses one of the plyometric exercises. While the difference in training is also influenced by the strength and speed training, for excellence in research now, which is to have fewer plyometric training methods and the strength of the muscles involved is theoretically able to increase the speed and power of the limb muscles [13].

Based on the training and mean tests results, it was stated that the jumping jacks exercise gave better results than the provision of tuck jump training to the strength of the limb muscles and limb muscle power in Pencak Silat Twigs Malang Athletes. This can be seen and analyzed from the process of jumping jacks exercise done by jumping the goal that is arranged parallel to repeatedly and holding the weight of the body resting on the legs and jumping jacks exercise results in functional adaptation of muscles and muscle coordination for the better. In contrast, tuck jump movement exercises are slightly more accessible because no barriers block when doing jumps. The results of significant tests using posthoc tests stated that there was a substantial difference in the influence of the training of jumping jacks and tuck jumps on the strength of the limb muscles and power of the limb muscles in Pencak Silat Twigs Malang Athletes. This is in line with the results of research conducted by Miller (2007) that training devoted to improving strength and power when using plyometric exercises contributes to improved performance by increasing strength and power simultaneously with motion awareness [14]. In line with the results of Milic's research (2008), plyometrics can contribute to increased speed, jumping and jumping, strength, and strength of the limb muscles [15]. Therefore the jumping jacks group is better than the tuck jump group and control group because the jumping jacks movement performs jumping movements forward or forward. In contrast, for the tuck jump movement, only do vertical movements upwards by analyzing motion biomechanically. Thus that is a significant influence for the difference of jumping jacks group with tuck jump and control.

\section{CONCLUSION}

There was an increase in leg muscle strength and leg muscle strength in each group after exercising. In addition, there are differences in the effect between the three groups seen from the increase in leg muscle strength and strength, where the jumping jack exercise has a better result than the tuck jump exercise and the control group on leg muscle strength and leg muscle strength.

\section{REFERENCES}

[1] T. Rodica and E. Nurmai, "The Effects of Leg Muscle Strength Exercises on Students' Front Kick Abilities in Pencak Silat Extracurricular Activities at KH. Ahmad Dahlan Islamic Boarding School Teluk Kuantan," Proc. 1st Prog. Soc. Sci. Humanity. Educ. Res. Symp. (PSSHERS 2019), vol. 464, no. Psshers 2019, pp. 887890, 2020, doi: 10.2991/assehr.k.200824.197.

[2] T. Juwanda, Zulrafli, and Kamarudin, "Contributions of Leg Power Muscle on Sickle Kick Ability of Pencak Silat Athletes," 1st Int. Conf. Phys. Educ. (ICPE 2019), vol. 460, no. Ice 2019, pp. 185-187, 2020.

[3] E. Arianda, T. Rustiadi, D. Wira, and Y. Kusuma, "The Effect of Plyometric and Resistance Training on Increasing The Speed And Explosive Power of The Leg Muscles," J. Phys. Educ. Sport., vol. 10, no. 2, pp. 200210, 2021.

[4] H. Z. Faidlullah and K. D. Roselina, "Depth Jump Dan Knee Tuck Jump Terhadap Hasil Tendangan Lambung Atlit Sepak Bola Pemula Di Smp Al-Firdaus Surakarta Program Studi D Iv Fisioterapi," J. Fisioter., vol. 9, no. 1, 2009.

[5] D. P. Ayuningtyas, J. Hartono, K. Rahayu, J. Pendidikan, and F. I. Keolahragaan, "Pengaruh Latihan Side Hop Dan Jump To Box Terhadap Power Tungkai," Unnes J. Sport Sci., vol. 4, no. 2, pp. 11-17, 2015, [Online]. Available: Unnes Journal of Sport Sciences 4 (2) (2015)\%0AUnnes Journal of Sport Sciences h.

[6] T. Bompa and C. Buzzichelli, Periodization Training for Sports-3rd Edition. 2015.

[7] T.; H. G. G. Bompa, "Periodization-6th Edition: 
Theory and Methodology of Training - Bompa, Tudor O., Buzzichelli, Carlo - Google Books," 2009. https://books.google.co.id/books?hl=en\&lr=\&id=2f9Q DwAAQBAJ\&oi=fnd\&pg=PR1\&ots=rwRZSDp6zq \& sig=2xA26uBpS7neJY3CA5RXSH4t10s\&redir_esc $=y$ $\# \mathrm{v}=$ onepage \&q\&f=false (accessed Oct. 29, 2019).

[8] R. M. HARMAN, EVERETT A.; ROSENSTEIN, MICHAEL T.; FRYKMAN, PETER N.; ROSENSTEIN, "The effects of arms and countermovement on vertical jumping," Med. Sci. Sport. Exerc., vol. 22, no. 06, pp. 825-833, 1990.

[9] M. Y. Baharuddin, "Biomechanics analysis on muscle activation during jumping jack exercise," J. Sport. Sci. Phys. Educ., vol. 6, no. November 2017, 2021, DOI: 10.37134/jsspj.vol6.2.3.2017.

[10] R. A. Fauzi, A. Suherman, I. Safari, E. Saptami, and H. Article, "Journal of Physical Education, Health and Sport Simple Exercises at Home During Social Distancing to Avoid Cov-," J. Phys. Educ. Heal. Sport, vol. 7, no. 2, pp. 31-37, 2020.

[11] M. Farid, D. Ramadi, M. Kes, N. Wijayanti, and S. P. M. Pd, "The Effect Knee Tuck Jump Exercise Toward Power Of Leg Muscle Of Student Extracurricular Volleyball WomenS SMAN 11 Pekanbaru Otot Tungkai Pada Siswi Ekstrakurikuler," vol. 3, pp. 1-12, [Online]. Available: https://media.neliti.com/media/publications/199169none.pdf.

[12] S. Wahyuni; and Donie, "VO2max, Daya Ledak Otot Tungkai, Kelincahan Dan Kelentukan Untuk Kebutuhan Kondisi Fisik Atlet Taekwondo," J. Patriot, vol. 2, no. 2, pp. 1-13, 2020.

[13] S. H. P. Putera, H. Setijono, and O. Wiriawan, "Effect of Plyometric Hurdle Hops and Tuck Jump Training on Strength and Leg Muscle Power in Martial Arts Athletes at Kostrad Company-C Malang," Budapest Int. Res. Critics Linguist. Educ. J., vol. 2, no. 4, pp. 566-574, 2019, DOI: 10.33258/birle.v2i4.649.

[14] F. Fischetti, A. Vilardi, S. Cataldi, and G. Greco, "Effects of a plyometric training program on speed and explosive strength of lower limbs in young athletes," $J$. Phys. Educ. Sport, vol. 18, no. 4, pp. 2476-2482, 2018, doi: 10.7752/jpes.2018.04372.

[15] R. Yenes and D. Leowanda, "Latihan Plyometrik Front Jump dan Side Jump Tehadap Daya Ledak Otot Tungkai Atlet Bola Voli Perbedaan Pengaruh Differences In The Effect Of Plyometric Exercise Front Jump And Side Jump Against The Explosion Of Limbs In The Volleyball," J. Performa, vol. 4, no. 2, 2019. 